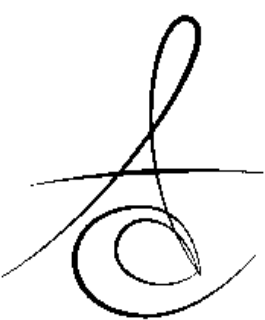

Makale Kodu/Article code: 2211

Makale Gönderilme tarihi: 26.03.2015

Kabul Tarihi: 03.07.2015

\section{THE USE OF PROLIFERATION MARKERS OF THE INFAMATUAR AND DEVELOPMENTAL ODONTOGENIC CYSTS}

\section{GELIŞ̧IMSEL VE İNFAMMATUVAR ODONTOJENİK KİSTLERDE PROLİFERASYON MARKERLARI}

Arş. Gör..Doğuhan TAŞCI*

Yrd. Doç. Dr.Fatih CABBAR*

Prof. Dr. M. Kemal ŞENÇi̇̈T*

\section{ABSTRACT}

Understanding of the pathogenesis of developmental and inflammatory cysts is important to determine surgical approach and important for the identifcation and prediction of prognosis of the cyst of the oral and maxillofacial region. The immunohistochemically histologic examinations gives information about the potential proliferation of cyst epithelium. Subsequently facilitates the identifcation and choice of treatment options. In this review, with the use of proliferation markers in the prognosis of developmental and inflammatory cysts examined immunohistochemically evaluated in light of the current literature.

Key Words: odontogenic cyst, proliferation markers

\section{ÖZET}

Ağız, Çene ve yüz bölgesinde gelişen gelişimsel veya inflammatuvar odontojenik kistlerin patogene zinin anlaşılması , cerrahi yaklaşımını belirlenmesi ve kistin prognozunun öngörülmesi açısından önemlidir İmmunohistokimyasal yöntemlerle yapılan histolojik incelemeler kist epitelinin proliferasyon potansiyeli hakkında bilgi vermektedir ve bununla birlikte proliferasyonun belirlenmesini ve tedavi seçeneklerinin tercihini kolaylaştırmaktadır. Bu derlemede proliferasyon markerlarının gelişimsel ve inflammatuvar odontojenik kistlerde immunohistokimyasal yöntemlerin kullanımı ile prognozun incelendiği güncel literatür bilgileri değerlendirilmiştir.

Anahtar kelimeler: odontojenik kist, proliferasyon markerları

It is known that the epithelial linings of odontogenic cysts are primarily composed of squamous epithelium, and various forms of metaplasia and degeneration are observed in these epithelial linings; such as, mucous cells, ciliated cells, parakeratinization and/or orthokeratinization and formation of hyaline bodies. It has been reported that the longer the tooth remains impacted the risk of cyst or tumor development increses. Malignancies such as carcinomas may also arise from cystic epithelium and such malign transformations have an incidence of $1 \%$ to $2 \%$. Variations in proliferation rates of odontogenic epithelial cells are suggested to have a paramount role in cyst and tumor pathogenesis. ${ }^{6,7}$

Recently a number of studies in this field are ongoing because there is a lack of detailed histopathological or immunohistochemical data about these have a lifelong capability to differentiate in odontogenic epithelium. ${ }^{4,5}$

*Yeditepe Üniversitesi, Diş Hekimliği Fakültesi, Ağız Diş ve Çene Cerrahisi AD 
lesions although odontogenic epithelium has an abnormal transformation potential. Today, as a result of previous studies odontogenesis is a well known prosses. On the other hand, etiology and pathogenesis of most lesions except for a few cystic lesions which are known to develop in consequence with inflammatory events are not well known yet and being searched. $^{8}$ It is, however, reported that some odontogenic cysts manifest clinically aggressive courses while some other histomorphologically immature odontogenic tumors have relatively milder aggressive characteristics in clinic. Why these lesions developing from the tissue rests in odontogenesis with a common histogenesis exert different clinicopathologic features from each other cannot be explained and still controversial. The literature points out that the research so far has focused on the pathogenesis of these lesions rather than their etiology. Although various approaches are being followed to investigate pathogenesis of lesions with an unknown etiology, immuhistochemical methods searching embryohistogenesis or proliferative characteristics of lesions stand for the majority of researches about odontogenic cysts and tumors. Current genetic and molecular researches report that treatment options might be managed by analyzing proliferation markers of aggressive neoplasms. ${ }^{9}$

Immunohistochemical methods are developed with the purpose of examining proliferating cell phenotypes through double staining techniques of cellcycle related antigens. ${ }^{10}$ Cellular proteins such as cyclins, proliferating cell nuclear antigens and histones having direct or indirect influence on cell proliferation have been identified. Such proteins, required by the DNA polymerase-a subunit and completion of cellcycle, have been reported to have an increased synthesis during interphase stage and disappear at the end of the mitosis. ${ }^{11,12}$ It has been proposed that such proteins might serve as markers about cell proliferation mechanisms. ${ }^{13}$ (There are immunohistochemical studies in which proliferation markers are used to investigate proliferative potentials of odontogenic cells. In this review we aim to analyze use and effecttiveness of commonly used proliferation markers such as Ki-67, p53, PCNA, minichromosome maintenance proteins (MCM). To this end we conducted an online search in Turkish and English publications from 1998-2011 available on Pubmed (National library of medicine, (www.pubmed.com) and Google (www.google.com) websites. In addition, manual search was implemented on relevant books, periodicals and printed materials available at the Library of Yeditepe University, Dentistry Faculty.

\section{Ki-67}

A proliferation marker used to demonstrate the proliferative cell number within the tumors, Ki-67, was initially utilized by Gerdes et al. in 1983. It has a wide usage as it is detectable by simple histopathological methods. ${ }^{14} \mathrm{Ki}-67$ recognizes the antigen within the proliferating cell nuclei and is indicative of division activity. ${ }^{15}$

While Ki-67 binding can be observed during the G1, S, G2, and M phases of cell-cycle it can not be detected at the early $\mathrm{G} 1$ phase. ${ }^{\mathbf{1 4}}$ Expression of this marker reaches to its maximum level during the $\mathrm{G} 2$ and $M$ phases. The detection of $\mathrm{Ki}-67$ in tumor tissues refer to the rate of cells in cycle. ${ }^{\mathbf{1 6}}$ Development of microwave technique in 1992 revealed MIB-1is an antigen equivalent to Ki-67. With the use of this technique, Ki-67, its use was limited only to fresh and frozen tissues, can be used on paraffin blocks as well. ${ }^{17}$ In their study comparing immunohistochemical values of monoclonal and polyclonal Ki-67, PC10, MIB1 , and JC1 antibodies in malign and normal tissue samples Rose et al. described MIB-1 and polyclonal Ki67 as proliferation markers with possible routine practice. ${ }^{18} \mathrm{Ki}-67$ is a widely used marker to identify the proliferative activities and transformation processes of cells into carcinoma in premalign, dysplastic or tumoral formations of oral cavity. ${ }^{19,20}$ It has been concluded that the increased Ki-67 expression may be an early stage sign of the changes in oral mucosa. ${ }^{\mathbf{2 1}}$ Moreover, a higher expression in inflammatory follicles and in turn an elevated cell turnover of DF epithelial structures can be evaluated. ${ }^{22}$ Importance of $\mathrm{Ki}-67$ expression in tumor prognosis is a subject of debate. ${ }^{23}$ In literature there are some studies which demonst- rate a poor prognosis in tumors with a high proliferation rate. But there are also other researches which indicate that Ki67 expression is not a good indicator for tumor prognosis. $^{\mathbf{2 4}}$ Some authors have stated a significant correlation between malign transformation and Ki-67 expression. ${ }^{25}$ In addition to that $\mathrm{Ki}-67$ was reported to have usage both in diagnosis and determination of 
treatment efficiency and capability to demonstrate susceptibility of tumor to chemotherapy and radiotherapy. ${ }^{26}$ Toi et al. assessed Ki-67 index of the cancerous tissue during the treatment period concluding that the change in Ki-67 expression in comparison to basal levels is a determinative factor to offer customized treatments and as a result more effective treatments might be administered. ${ }^{27}$ Ki-67 expression was pointed out as an important factor in finding out the recurrence. ${ }^{28}$ Kropveld et al. ${ }^{29}$ have shown T2 laringeal carcinoma tumor cells detected to express high levels of Ki-67 have a very well response to radiotherapy and a low recurrence in these cells In their study on keratocystic odontogenic tumor (KOT) Mendes et al. highlighted that relapse potential of KOTs cannot be clearly decided using surgical methods and have associated proliferation markers such as PCNA, Ki-67 and p53 with recurrence as well as progression rate of KOT.

In spite of its use in many lesions it is also stated that remember $\mathrm{Ki}-67$ proliferation marker has a low efficiency in certain lesions. Souza et al. have concluded that despite it presents a more aggressive clinical picture central giant cell lesion has a lower proliferative activity in comparison to peripheral giant cell lesion and therefore the tissue biology of central giant cell lesion can not be based on the this marker. ${ }^{30}$ Lack of Ki-67 expression in G0 phase of cell proliferation whereas it is active in G1, S, and G2 phases has been underlined as an important indicator by Bullwinkell et al. ${ }^{31}$ It is therefore suggested that it might not be possible to detect the proliferation of cells at the G0 stage using this marker.

\section{p53 Tumor Suppressor Gene}

p53 gene was described for the first time in 1979 by Arnold Levine at University of Princeton. It is a phosphoprotein made up of 393 amino acids weighing 53 kilodaltons. p53 was believed to be an oncogene until 1989. In 1989 Bert Vogelstein reported that it functions as a tumor suppressor gene while mutant form of p53 acts in tumor formation. ${ }^{32}$

In following years $\mathrm{p} 53$ gene was reported to have an essential role in a number of cellular events such as cell cycle control, DNA repair, genome stability, apoptosis, differentiation and angiogenesis. ${ }^{33}$ Called as the guardian of genome, p53 protein is shown to inhibit proliferation of cells with DNA damage. The reported ways of exerting this action is either to cease cell cycle until DNA damage is repaired or to target the cell to enter apostosis in case the cell fails to repair. ${ }^{33}$

Wild type p53 gene is located in human chromosome 17 and it is reported as the most frequently mutated gene in cancer. ${ }^{32}$ Suppressing the cell's growth and transformation, this gene is a leading proliferation control factor. ${ }^{33}$ Immunohistochemical detection of p53 gene is argued to be difficult as it exists in low quantities in health tissues with a short half-life, 6-20 minutes. ${ }^{32}$ On the other hand, while wild type p53 gene acts as a tumor suppressor, mutant form has a tumorigenic activity. ${ }^{34}$ Therefore, in immunohistochemical studies, mutant p53 expression is more usable.

Since p53 is the most frequently mutated gene in human cancers, it is known to be effective in disruption of the normal cell growth control through leading the accumulation of genetic alterations. Researches associate a positive p53 gene result to tumor development. p53 gene expression have been shown in squamous cell carcinomas of head, neck and mouth $^{35}$, osteosarcomas of jaw ${ }^{36}$, malign oral mucosal lesions ${ }^{37}$, oropharyngeal squamous cell cancers, lymphomas, reactive lymph nodes, and lymphatic malignancies $^{38}$, KOT and ameloblastomas. ${ }^{39}$ Shear have detected p53 in 11 of 13 KOTs, 6 of 9 ameloblastomas, and both of 2 odontogenic carcinomas while no p53 detection is reported in any of the dentigerous or radicular cyst samples. ${ }^{40}$ These results are also supported by other studies. ${ }^{41}$ Nevertheless it was also reported that p53 protein is only detectable in KOTs among the jaw cysts along with a higher PCNA existence dentigerous or radicular cysts compared to KOTs. ${ }^{42}$ Öktemer, reports higher expression of this marker may help us explain the aggressive course of KOT in comparison to other odontogenic cysts. ${ }^{39}$

\section{Proliferating Cell Nuclear Agent (PCNA)}

PCNA was identified in 1978 by Miyachi et al. in the sera from a systemic lupus erythematosus patient. It has been named after its intense detection in proliferating cell nuclei. PCNA is formed by 262 amino acids. ${ }^{43}$ Mathews et al. have revealed out that PCNA and cyclin are actually the same protein. ${ }^{44}$

PCNA is observable during the late G1 phase of the cell-cycle and reaches a peak S-phase. Later in M phase and quiescent state immunohistochemically PCNA expression is not found and PCNA half-life is 
reported to be 20 hours. ${ }^{45}$

PCNA expression is associated both with the active DNA replication and with DNA damage resulting in the carcinogenesis which leads the interpretation that PCNA expression might be used as a marker of irregular cell proliferation. However, it may exert higher rate of unassociated deviations when compared to other proliferation markers. In comparison to Ki-67, PCNA specifically gains attention during the $S$ phase. ${ }^{45}$ Decrease in its expression during the $S$ phase ${ }^{46}$ stands for a reduced proliferative activity. ${ }^{46}$

In a similar manner to its use in hematological malignancies, malignancies of gastrointestinal tract; breast skin, and urinary system malignancies, PCNA find its use as a proliferation marker in maxillofacial region, as well. ${ }^{47-49}$ Shear has associated PCNA with cellular replication reporting that it is stimulated by growth factors and exists in higher quantities in KOTs than in dentigerous cysts and radicular cysts. In line with this he discusses its expression is associated with the aggressiveness of the lesion. ${ }^{40}$ On the other hand, while p53 and Ki-67 expressions were reported to be useful in differential diagnosis of glandular odontogenic cyst, PCNA expression is not useful. ${ }^{50}$

\section{Minichromosome Maintenance Proteins}

In all eukaryotic cells, initiation of DNA synthesis occurs at defined replication sites. ${ }^{51}$ Proteins forming the pre-replicative complex are required so that the DNA synthesis can take place. ${ }^{52}$ Initially described in the yeast Saccharomyces cerevisiae the new proliferation marker, MCM proteins take part in the formation of the pre-replicative complex and therefore they are necessary proteins to initiate and regulate DNA synthesis. ${ }^{51,53}$ MCM 2-7 proteins are structurally similar to each other and have similar action mechanisms to other markers in the cell cycle. ${ }^{54}$ MCM binds to the DNA regions to which Cdc6 proteins and origin recognition complex have already bond sequentially forming altogether the pre-replication complex. ${ }^{55}$ Allowing the DNA synthesis this complex also restricts DNA replication irreversibly to once per cell cycle thus ensuring the genome stability. ${ }^{55,56}$ However, failure to regulate the activity of MCM proteins indicates a disruption in cell's genome stability and occurrence of an abnormal increase in proliferation. $^{57}$

Existence and activity of MCM proteins during the cell cycle are well defined. It is reported that the protein is observed at all phases of cell-cycle but it disappears once the cell-cycle is completed or the cells undergoes differentiation. On the other and these proteins are not observable in cells with DNA repair mechanisms ${ }^{51}$.

Recent studies highlights MCM proteins as one of the best proliferation markers to estimate tumor formation ${ }^{58}$ Taking these properties into consideration MCM proteins are documented to have a possible use as specific markers of proliferative cells ${ }^{59}$, their immunoreactivity is of potential clinical significance in certain malign tumors ${ }^{59}$, and they might be useful in determination of prognosis in lung and prostate cancer. ${ }^{60,61}$ They are also stated to be important in identification of high risk groups in some cancer types such as stage $\mathrm{T} 1$ bladder cancer. ${ }^{62}$ The marker is also reported to provide reliable and objective findings in histopathological classification of larynx lesions. Chatrath et al. found increasing Ki-67 and MCM-2 expression in epithelia in: normal larynx, laryngeal dysplasia and laryngeal squamous cell carcinoma (SCC) respectively. They argued that MCM-2 expression can be used safely. ${ }^{63}$ Proliferation marker MCM-2 has been investigated in healthy dental follicles. Cabbar et al. revealed out an higher proliferation rate in dental follicles of the asymptomatic impacted third molars when compared to healthy gingiva reporting $\mathrm{MCM}-2$ expression indicates that odontogenic cells of asymptomatic dental follicles are likely to be actively proliferating. They also observed a greater expression in inflammatory follicles and discussed this elevation is supporting the view that epithelial structures in DF have an increased cell turnover. ${ }^{64}$ Another research investigating the levels of markers Ki-67 ve MCM-2, has explained the high expression of MCM-2 by lack of Ki- 67 expression during the early G0 and early G1 phases of cell-cycle. ${ }^{65}$ Therefore MCM-2 expressions are reported to provide more precise results in cytological diagnosis. ${ }^{66}$

\section{DISCUSSION AND CONCLUSION}

Variations in the proliferation rates of oral epithelium have an important role in the pathogenesis of cysts and tumors derived from odontogenic epithelial rests, dental follicles and epithelial lining of the oral mucosa. ${ }^{67}$ For that reason, determination of the proliferation potentials of these epithelial cells 
gains importance in treatment and prognosis of these lesions. Immunohistochemical researches employing proliferation markers such as $\mathrm{Ki}-67, \mathrm{p} 53$, PCNA, and MCM-2 have been conducted in order to specify proliferative potential of epithelia. But these researches are reporting controversial results.

Considering Ki-67 proliferation marker which is already in routine use and is a possible indicator of genetic abnormalities co-existing with the premalignant and malignant lesions of oral cavity. ${ }^{40,68}$ In literature there are some studies which demonstrate a poor prognosis in tumors with a high proliferation rate. But some authers indicate that Ki-67 expression is not informative about tumor prognosis. In addition to that Ki-67 was reported to have usage both in diagnosis and determination of treatment efficiency and capability to demonstrate susceptibility of tumor to chemotherapy and radiotherapy. ${ }^{24}$ It is routinely in use for the jaw cysts but it should be taken into consideration that $\mathrm{Ki}-67$ expression cannot be detected in G0 phase. So it might cause false negative results if the proliferating cells are in this stage $^{31}$. In a recent study, $\mathrm{Ki}-67$ was studied in tooth germs and it is shown that proliferating cells most likely influence the tooth germ. ${ }^{69}$

Since p53 is the most frequently mutated gene in human cancers, it is established to be effective in disruption of the normal cell growth control through leading the accumulation of genetic alterations. Researches associate a positive p53 gene result to tumor development but unfortunately not for the jaw cysts $^{35}$. Proliferation rates of odontogenic epithelia of jaw cysts are also studied with this marker. It is reported that p53 is only detectable in KOTs among the jaw cysts and it is probaply because of the KOTs tumorogenic origin ${ }^{40}$. Regarding this data p53 is not a referred marker for jaw cysts.

PCNA expression is reported to have a possible use of irregular cell proliferation. PCNA expression is associated both with the active DNA replication and with DNA damage resulting in the carcinogenesis. In the studies which investigated the effect of this marker, has reported that PCNA expression is associated with cellular replication in dentigerous cyst, radicular cyst and glandular odontogenic cyst and it is related with the aggressiveness of the lesions but has no use for the differential diagnosis. ${ }^{50,40}$ However, higher rate of deviations were shown compared to other proliferation markers. ${ }^{45}$ Taking part in the formation of pre-replicative complex, MCM proteins are required to initiate and regulate DNA eukaryotic synthesis. Failure to regulate the activity of MCM proteins have been associated with a disruption in cell's genome stability and occurrence of an abnormal increase in proliferation. ${ }^{55-57}$ Recent studies highlights MCM proteins as one of the best proliferation markers to estimate possible tumor formation. ${ }^{53}$ Taking these properties into consideration MCM proteins are documented to have a possible use as specific markers of proliferative cells their immunoreactivity is reported to have a potential clinical significance in certain malign tumors. ${ }^{59}$ It is reported that the MCM-2 expression is higher in follicles with squamous metaplasia which is indicating cystic transformation. Therefore authors suggested that MCM-2 is a valuable diagnostic tool for cystic transformations. ${ }^{64-66}$

As a result of the literature review, the need of implementing histopathological, immunohistochemical, and clinical studies examining larger number of cases arises as a common view. These should investigate the proliferative potential of developmental and inflammatory cysts directed to improve the diagnosis and prognosis of lesions through association of findings with the clinical parameters.

Ki-67 proliferation marker is already in routine use while action mechanisms and safety of other proliferation markers have to be determined and/or reliable markers must be developed to obtain more accurate results by their use.

\section{REFERENCES}

1. Kim J, Ellis GL. Dental follicular tissue misinterpretation as odontogenic tumors. J Oral Maxillofac Surg, 1993; 51: 76767.

2. Stanley HR, Krogh H, Pankkuk E. Age changes in the epithelial components of follicles (dental sacs) associated with impacted third molars. Oral surg Oral Med Oral Pathol, 1965; 19: 128-39.

3. Bhaskar SN. Orban's Oral Histology and Embryology . Mosby Year Book. St. Louis. 1991.

4. EI-Mofty S.K.: Introduction: Seminars Diagnostic Pathology, 1999; 16:269-70.

5. Regezi J.A., Sclubba J.J., Jordon R.C.K.: Oral Pathology: Clinical Pathologic Correlations. 4th Ed., Saunders, St. Louis, Missouri, 2003. 
6. Schwimmer AM, Aydın F, Morrison SN. Squamous cell carcinoma arising in residual odontogenic cyst. Report of a case and review of literature. Oral Surg Oral Med Oral Pathol, 1991; 72: 218-21.

7. Stoelinga PJW, Bronkhorst FB. The incidence, multiple presentation and recurrence of aggresive cysts of the jaws. J Craniomaxillofac Surg, 1998; 16: 184-95,

8. Borah GL, Aziz SR. Tumors of the mandible. In: Mathes SJ, Hentz VR, editors. Plastic surgery. Vol. 5, 2nd ed. Philadelphia: W. B. Saunders, 2006; 91157.

9. Mendes RA, Carvalho J, Waal I. Characterization and management of the keratocystic odontogenic tumor in relation to its histopathological and biological features. Oral Oncology, 2010; 46: 21925.

10. Hall PA, Levision DA. Review: assesments of cell proliferation in histological material. J Clin Pathol, 1990; 43: 184-92.

11. Bravo R, Frank R, Blundell PA, Macdonald-Bravo $H$. Cyclin/PCNA is the auxiliary protein of DNA polymerase-delta. Nature, 1987;326: 515-7.

12. Schumperli D. Cell-cycle regulation of histone gene expression. Cell, 1986; 45: 471-2.

13. Lee M, Nurse P. Cell cycle control genes in fission yeast and mammalian cells. Trends Genet, 1988; 4: 287-90.

14. Gerdes J, Lemke H, Baisch $H$, Wacker HH, Schwab $\mathrm{U}$, Stein $\mathrm{H}$. Cell cycle analysis of a cell proliferationassociated human nuclear antigen defined by the monoclonal antibody Ki-67. J Immunol, 1984; 133: 1710-5.

15. Sasaki K, Murakami T, Kawasaki M, Takahashi M. The cell cycle associated change of the Ki-67 reactive nuclear antigen expression. J Cell Physiol, 1987; 133: 579-84.

16. Duchrow M, Gerdes J, Schulter C: The proliferation-associated Ki-67 protein: Definition in molecular term. Cell Prolif, 1997; 57: 235- 42.

17. Cattoretti G, Becker MH, Key G, Duchrow M, Schluter C, Galle J, Gerdes J. Monoclonal antibodies against recombinant parts of the $\mathrm{Ki}-67$ antigen (MIB 1 and MIB 3) detect proliferating cells in microwave-processed formalin-fixed paraffin sections. J Pathol, 1992; 168: 357-63.

18. Rose DSC, Maddox PH, Brown DC. Which proliferation markers for routine immunohistology?
A comparison of five antibodies. J Clin Pathol, 1994; 47: 1010-4.

19. Liu SC, Szanto AJPK. Markers of proliferation in normal and leukoplakic oral epithelia. Oral Onc, 2000; 36: 145-51.

20. Acay RR, Felizzola CR, Araujo NS, Souza SOM. Evaluation of proliferative potential oral lichen planus and oral lichenoid lesions using immunohistochemical expression of p53 and Ki67. Oral Oncol, 2006; 42: 475-80.

21. Macluskey M, Ogden GR, Green M, Chisholm DM, Schor SL, Schor AM. The association between epithelial proliferation and disease progression in the oral mucosa. Oral Oncol, 1999; 35: 409-14.

22. Edamatsu M, Kumamoto $H$, Ooya K, Echigo S. Apoptosis-related factors in the epithelial components of dental follicles and dentigerous cysts associated with impacted third molars of the mandible. Oral Surg Oral Med Oral Pathol Oral Radiol Endod, 2005; 99: 17-23.

23. Ananthanarayanan V, Deaton RJ, Yang XJ, Pins $\mathrm{MR}$, Gann PH. Alteration of proliferation and apoptotic markers in normal and premalignant tissue associated with prostate cancer. BMC Cancer, 2006; 6: 73-102.

24. Chrysomali E, Nikitakis NG, Tosios K, Sauk JJ, Papanicolaou SI. Immunohistochemical evaluation of cell proliferation antigen Ki- 67 and apoptosisrelated proteins $\mathrm{Bcl}-2$ and caspase-3 in oral granular cell tumor. Oral Surg Oral Med Oral Pathol Oral Radiol Endod, 2003; 96: 566-72.

25. Piattelli A, Rubini C, Fioroni M, Iezzi G, Santinelli A. Prevalence of p53, bcl-2, and Ki-67 immunoreactivity and of apoptosis in normal oral epithelium and in premalignant and malignant lesions of the oral cavity, J Oral Maxillofac Surg, 2002; 60: 532-40.

26. Raybaud-Diogène $H$, Fortin A, Morency R, Roy J, Monteil RA, Têtu $B$. Markers of radioresistance in squamous cell carcinoma of the head and neck: A clinicopathologic and immunohistochemical study. J Clin Oncol, 1997; 15: 1030-8.

27. Toi M, Saji S, Masuda N, Kuroi K, Sato N. Ki67 index changes, pathological response and clinical benefits in primary breast cancer patients treated with 24 weeks of aromatase inhibition Breast, 2011; 23-7.

28. Kuroyanagi N, Sakuma H, Miyabe S, Machida J, 
Kaetsu A, Yokoi $M$, et al. Prognostic factors for keratocystic odontogenic tumor (odontogenic keratocyst): analysis of clinico-pathologic and immunohistochemical findings in cysts treated by enucleation. J Oral Pathol Med, 2009; 38: 386-92.

29. Kropveld A, Slootweg PJ, Blankenstein MA, Terhaard $\mathrm{CHJ}$, Hordijk GJ. Ki-67 and p53 in T2 Laryngeal Cancer. Laryngoscope, 1998; 108: 154852.

30. Souza PEA, Mesquita RA, Gomez RS. Evaluation of PCNA, Ki-67, MDM2 and Agnor in oral peripheral and central giant cell lesions. Oral Diseases, 2000; 6: 35-9.

31. Bullwinkel J , Baron-Lu“hr B , Lu“de - mann A, Wohlenberg C, Gerdes J, Scholzen T. Ki-67 protein is associated with ribosomal RNA transcription in quiescent and proliferating cells. J Cell Physiol, 2006; 206: 624-35.

32. Barnes D.M., Hanby A.M., Gillett C.E., Mohammed S., Hodgson S., Borrow L.G. ve di-erleri. Abnormal expression of wild type p53 protein in normal cells of cancer family patient, Lancet, 1992; 340: 25963.

33. Cox, L.S. Multiple pathways control cell growth and transformation: Overlapping and independent activities of p53 and p21. Journal of Pathology, 1997; 183: 134-40.

34. Sionov V, Haupt Y. The cellular response to p53 : the decision between life and death. Oncogene, 1999; 18: 6145-57.

35. Matsumura, T., Yoshihama, Y., Kimura, T., Shintani, S. ve Alcalde, R.E. p53 and MDM2 expression in oral squamous cell carcinoma. Oncology, 1996; 53: 308-12.

36. Olivera, P., Nogueria, M., Pinto, A. ve Almeida, O. Analysis of $\mathrm{p} 53$ expression in osteosarcoma of the jaw: Correlation with clinicopathologic and DNA ploidy findings. Human Pathology, 1997; 28: 13615.

37. Ogden, G. R., Kiddie, R.A., Lunny, D. P., Lane, D.P. Assesment of p53 protein expression in normal, benign and malignant oral mucosa. Journal of Pathology, 1992; 166: 389-94.

38. Sioni, Y., Paako, P., Alaviakko, M., Vahakangas, K. p53 expression in lymphatic malignancies. Journal of Clinical Pathology, 1992; 45: 1011-4.

39. Öktemer K. Dentigeröz kist, odontojenik keratokist ve ameloblastomalarda p53 tümör supresör genin ve indüklenebilir nitrik oksit senteaz enziminin karşılaştırmalı olarak immunohistokimyasal olarak incelenmesi, Hacettepe Üniversitesi, doktora tezi, 2007.

40. Shear M. Odontogenic keratocyst: natural history and immunohis- tochemistry. Oral and Maxillofacial Surg. Clinics of North America 2003; 15: 347-62.

41. Gaballah E, Tawfik M. Immunohistochemical analysis of P53 protein in odontogenic cysts. The Saudi Dental J, 2010; 22: 167-70.

42. Kocakahyaoglu B, Çetiner S. Odontojenik keratokistlerin tanı ve tedavilerine güncel yaklaşımlar, Gazi Üni Diş. Hek. Fak. Dergisi 2007; 24: 119-23.

43. Karaçaylı Ü. Ameloblastoma ve ameloblastik epitel içeren diğer odontojenik tümörlerin nükleer morfometrik değerlendirilmesi GATA 2006.

44. Mathews MB. Bernstein RM, Identity of Proliferating Cell Nuclear Agent and Cyclin. Nature, 1984; 309: 374-6.

45. Ogata K, Kurki P, Celic J. Monoclonal antibodies to a nuclear protein associated DNA replication. Exp Cell Res, 1986; 168: 476-86.

46. Tanaka T, Kohno H, Sakata K, Yamada Y, Hirose Y, Sugie S, Mori $H$. Modifying effects of dietary capsaicin and rotenone on 4-nitroquinoline 1oxide-induced rat tongue carcinogenesis. Carcinogenesis 2002; 23: 1361-7.

47. Runnebaum IB,Stickeler E. Epidemiological and molecular aspects of ovarian cancer risk. J Canc Res Clin Oncol, 2001; 127: 73-9.

48. Berek JS, Adashi EY, Hillard PA, Jones HW. Ovarian cancer. Novak's Gynecology Textbook, 1996; 28, 987-1021.

49. Miyachi K, Fritzler MJ, Tan EN. Autoantibody to nuclear antigen in proliferatif marcers. J Immunology, 1978; 121: 2228-34.

50. Yılmaz D, Aytemiz C, Oygür T. Odontojenik Keratokist. Gazi Üniversitesi Diş Hekimliği Fakültesi Dergisi, 1989; 6,1: 225-31.

51. Maiorano D, Lutzmann M, Mechali M. MCM proteins and DNA replication. Curr Opin Cell Biol, 2006; 18: 130-6.

52. Newlon CS. Putting it all together: building a prereplicative complex. Cell, 1997; 91: 717-20.

53. Freeman A, Morris LS, Mills AD, Stoeber K, Laskey RA, Williams $\mathrm{GH}$, Coleman N. Minichromosome maintenance proteins as biological markers of 
dysplasia and malignancy. Clin Cancer Res, 1999; 5: 2121-32.

54. Thommes $P$, Fett R, Schray B, Burkhart R, Barnes $M$, Kennedy C, Brown NC, Knippers R. Properties of the nuclear P1 protein, a mammalian homologue of the yeast MCM 3 replication protein. Nucl Acids Res, 1992; 20: 1069-74.

55. Romanowski $P$, Madine MA. Mechanisms restricting DNA replication to once per cell cycle: the role of Cdc6 and ORC. Trends Cell Biol, 1997; 7: 9-10.

56. Bell SP, Dutta A. DNA replication in eukaryotic cells. Annu Rev Biochem, 2002; 71: 333-74.

57. Bailis JM, Forsburg SL. MCM proteins: DNA damage, mutagenesis and repair. Curr Opin Gen Devel, 2004; 14: 17-21.

58. Maiorano $D$, Lutzmann M, Mechali M. MCM proteins and DNA replication. Curr Opin Cell Biol, 2006; 18: 130-6.

59. Pindborg JJ, Reichart P, Smith CJ, van der Waal I. World Health Organization: histological typing of cancer and precancer of the oral mucosa. Springer-Verlag, Berlin, 1997.

60. Meng MV, Grossfeld GD, Williams GH, Dilworth S, Stoeber K, Mulley TW, Weinberg V, Carroll PR, TIsty TD. Minichromosome maintenance protein 2 expression in prostate: characterization and association with outcome after therapy for cancer. Clin Cancer Res, 2001; 7: 2712-8.

61. Wharton SB, Chan KK, Anderson JR, Stoeber K, Williams GH. Replicative Mcm2 protein as a novel proliferation marker in oligodendrogliomas and its relationship to Ki67 labelling index, histological grade and prognosis. Neuropathol Appl Neurobiol, 2001; 27: 305-13.

62. 88 Krüger S, Thorns C, Stocker W, Muller-Kunert E, Bohle A, Feller AC. Prognostic value of MCM2 immunoreactivity in stage $\mathrm{T} 1$ transitional cell carcinoma of the bladder. Eur Urol, 2003; 43: 13845.

63. Chatrah P, Scott IS, Morris LS, Davies RJ, Rushbrook SM, Bird K, Vowler SL, Grant JW, Saeed IT, Howard D, Laskey RA, Coleman N. Aberrant expression of minichromosome maintenece protein-2 and $\mathrm{Ki}-67$ in laryngeal squamous epithelial lesions. Bri J Cancer, 2003; 89: 1048-54.

64. Cabbar F, Guler N, Comunoglu N, Sencift K, Cologlu S. Determination of potential cellular proliferation in the odontogenic epithelia of the dental follicle of the asymptomatic impacted third molars. J Oral Maxillofac Surg, 2008; 66: 2004-11,.

65. Gonzalez MA, Pinder SE, Callagy G, Vowler SL, Morris LS, Bird K, Bell JA, Laskey RA, Coleman N. Minichromosome Maintenance Protein 2 is a strong independent prognostic marker in breast cancer. J Clin Oncol, 2003; 21: 4306-13,.

66. Scott IS, Odell E, Chatrath P, Morris LS, Davies RJ, Vowler SL, Laskey RA, Coleman N. A minimally invasive immunocytochemical approach to early detection of oral squamous cell carcinoma and dysplasia. Br J Cancer, 2006; 94: 1170- 5,.

67. Muzio L, A. Santarelli, R. Caltabiano, C. Rubini, T. Pieramici, A. Fior, L. Trevisiol, F. Carinci, R. Leonardi, P. Bufo, S. Lanzafame, A. Piattelli: p63 expression in odontogenic cysts. Int. J. Oral Maxillofac. Surg, 2005; 34: 668.

68. Senguven B, Gultekin SE, Uluoğlu O. evaluation of proliferation index in osteosarcoma of jaws. J Dent Fak Ataturk Uni, 2013; 23: 75-81.

69. Danijela Kalibović Govorko, Tina Bečić, Katarina Vukojević, Snježana Mardešić-Brakus, Dolores Biočina-Lukenda, Mirna Saraga-Babic. Spatial and temporal distribution of $\mathrm{Ki}-67$ proliferation marker, $\mathrm{BCl}-2$ and Bax proteins in the developing human tooth Archives of Oral Biology, Volume 55, Issue 12, December 2010, Pages 1007-16.

\section{Yazış̧ma Adresi}

Arş. Gör. Doğuhan TAŞCI,

Yeditepe Unv.

Dis Hekimligi Fak.

No:238 Bagdat Cd 34728

Goztepe Istanbul.

Tel: +902163636044

Fax: +902163636211

Email: dogutasci@gmail.com 